\title{
STRATEGI EKSPANSI SALES TERRITORY MANAGEMENT DALAM MENINGKATKAN PERTUMBUHAN PENJUALAN STUDI KASUS PADA PT. KARYA ANUGERAH JAYA CABANG LAMPUNG
}

\author{
Husna Purnama ${ }^{(1)^{*}}$, Maristiana Ayu ${ }^{(2)}$, Astri Ratna Sari ${ }^{(3)}$ \\ Fakultas Ekonomi Universitas Sang Bumi Ruwa Jurai \\ husnapurnama@fe.saburai.ac.id,maristiana2017@gmail.com,astriratnasarii@gmail.com
}

\begin{abstract}
Abstrak. Penelitian ini bertujuan untuk mengetahui strategi ekspansi teritory sales dalam meningkatkan pertumbuhan penjualan pada PT. Karya Anugerah Jaya Cabang Lampung. Jenis penelitian ini menggunakan metode deskriptif kualitatif. Pengumpulan data yang digunakan berupa data primer dan data sekunder. Teknik pengumpulan data yang digunakan adalah observasi, wawancara dan dokumentasi. Berdasarkan hasil penelitian diketahui bahwa strategi ekspansi sales territory management dalam meningkatkan pertumbuhan penjualan studi kasus yang digunakan PT. Karya Anugerah Jaya dalam memasuki pasar di Lampung adalah melakukan pemetaan wilayah, perencanaan pengelolaan wilayah, dan melakukan monitoring target pencapaian - evaluasi. Berdasarkan analisis SWOT dan Matriks SWOT menunjukkan bahwa PT. Karya Anugerah Jaya memiliki kekuatan dan peluang yang lebih besar dibandingkan dengan kelemahan dan ancaman artinya bahwa perusahaan dalam kondisi yang baik. Kekuatan yang dimiliki oleh PT. Karya Anugerah Jaya terletak pada kekuatan dari segi keuangan, merk dagang yang telah dikenal, perusahaan memiliki pengalaman yang kuat di industri pewarna makanan, sumber daya manusia yang berkompeten.
\end{abstract}

Kata Kunci : Sales Teritory Management, Pertumbuhan Penjualan

\section{PENDAHULUAN}

Persaingan dunia bisnis menuntut perusahaan untuk mempertahankan dan meningkatkan nilai perusahaan. Saat ini banyak perusahaan melakukan berbagai cara untuk terus mengembangkan bisnis nya, dengan terus melakukan inovasi produk seperti peluncuran produk baru (launching) dan peluncuran ulang suatu produk tertentu (relaunch) untuk meningkatkan daya beli konsumen terhadap produk kompetitor, meningkatkan kualitas sumber daya manusia (SDM), melakukan perluasan usaha atau ekspansi bisnis.(Pitoy et al., 2016).

Menurut Mulyadi (Mulyadi, 2016) definisi penjualan merupakan kegiatan yang dilakukan oleh penjual dalam menjual barang atau jasa dengan harapan akan memperoleh laba dari adanya transaksitransaksi tersebut dan penjualan dapat diartikan sebagai pengalihan atau pemindahan hak kepemilikan atas barang atau jasa dari pihak penjual ke pembeli.

Pertumbuhan penjualan merupakan ukuran mengenai besarnya pendapatan per saham perusahaan yang diperbesar oleh utang. Suatu perusahaan yang berada dalam industri yang mempunyai laju pertumbuhan yang tinggi, harus menyediakan modal yang cukup untuk perusahaan. Weston dan Copeland dalam Naray dan Mananeke menyebutkan bahwa jika penjualan dan laba meningkat maka akan meningkatkan pendapatan perusahaan, sebaliknya jika penjualan dan laba menurun maka akan menurunkan pendapatan perusahaan(Naray \& Mananeke, 2015).

Ekspansi bisnis merupakan aktivitas memperbesar atau memperluas bisnis dengan menciptakan pasar baru, 
memperluas fasilitas, menambah sumber daya manusia, dan lain sebagainya. (Purboningrum, 2018). Ekspansi juga bisa dilakukan sebagai peningkatan aktivitas ekonomi di dalam suatu bisnis, yang nantinya akan berwujud pada peningkatan kekuatan bisnis, peningkatan keuntungan, akses teknologi serta munculnya pelanggan baru dan lain sebagainya. Dengan berbagai keuntungan ini tentu saja ekspansi menjadi tujuan yang diharapkan oleh hampir setiap pelaku bisnis baik itu di perusahaan besar maupun kecil. Namun untuk mencapai titik tersebut bukanlah hal yang mudah.

Berbagai upaya dan perjuangan harus dilakukan agar proses perluasan tersebut tidak berhenti di tengah jalan. Dalam upaya melakukan ekspansi bisnis setidaknya diperlukan strategi yang tepat untuk menentukan keberhasilan sebuah penjualan. Salah satu strategi yang dapat dilakukan adalah melihat bagaimana bisnis atau perusahaan tersebut dalam mengelola wilayah penjualan atau biasa kita sebut sales territory management (manajemen wilayah penjualan) (Fajar, 2012). Dengan memahami bagaimana seharusnya sebuah perusahaan mengelola wilayah penjualan, maka perusahaan akan dapat mengetahui sebesar apa potensi bisnis suatu wilayah dan bisa menentukan, bagaimana cara yang paling efektif dan paling efisien untuk memperoleh hasil maksimal sesuai potensinya.

Sales Territory atau Wilayah Penjualan adalah suatu area atau daerah geografis tertentu yang didalamnya terdapat konsumen atau pelanggan yang memiliki potensi penjualan atau potensi bisnis yang dikelola oleh sales tim. (Kerjaya, 2016) Manajemen Wilayah Penjualan atau Sales Territory Management adalah metode pengelolaan sebuah wilayah penjualan atau sales territory mulai dari pengetahuan dan pemahaman tentang wilayah penjualan, penyusunan rencana pengelolaan, implementasi serta evaluasi terhadap metode pengelolaan dan hasil dari pengelolaan wilayah penjualan tersebut.

Menurut Frans M Royan sales territory Management adalah pengelolaan wilayah penjualan yang sudah direncanakan dan dipetakan sesuai dengan kondisi dan situasi wilayah yang ada.(Royan, 2014). Jadi sales territory management adalah sebuah aktivitas yang dilakukan secara periodik dan berkelanjutan yang bersifat dinamik. Bersifat dinamik, artinya manajemen wilayah penjualan tidak bersifat statis, mati atau kaku, melainkan bersifat dinamis dan fleksibel namun tetap ada standar-standar bakunya, mengikuti beberapa kondisi seperti kondisi pasar, kompetitor, goal setting perusahaan dan lain sebagainya.

Di dalam dunia distribusi tentunya akan sangat berhubungan dengan sales territory atau wilayah kerja penjualan karena merupakan bagian yang sangat vital dalam menentukan sukses tidaknya penjualan sehingga diperlukan suatu strategi yang terencana dalam menempatkan sales force dalam suatu wilayah sehingga dapat benarbenar berhasil dalam menguasai pasar wilayah tersebut.(Fajar, 2012)

PT.Karya Anugerah Jaya adalah salah satu perusahaan nasional yang bergerak di bidang industri pewarna makanan dan bahan tambahan pangan dengan membawa merek dagang $\mathrm{R} \& \mathrm{~W}$, ALCO, dan HANWE. PT.Karya Anugerah Jaya memproduksi bahan tambahan pangan baking powder, soda kue, citric acid, sodium siclamate, pemutih, vanili, dextrosa, dafcol white, pengenyal, cream of tar tar, gms, maizena, coklat bubuk, vx $-2 \%$, benzoat, sorbitol, meses, super tt, sapp, sodium sacharin , stpp , dan pemutih), emulsifier (sp ,ov, tbm) , perisa makanan, essence (flavour), pewarna makanan bubuk, pewarna makanan cair, dan pewarna tabur. Semua produk yang dihasilkan tersebut telah 
terdaftar di Badan Pengawas Obat dan Makanan (BPOM.RI) serta sudah memperoleh sertifikasi dari Majelis Ulama Indonesia (MUI). Kami memiliki 300 stock keeping unit (SKU) yang dipasarkan melalui 32 cabang perusahaan yang menjangkau ratusan ribu toko di seluruh Indonesia.

PT.Karya Anugerah Jaya cabang Lampung memiliki peran dan kontribusi yang sangat penting karena bertanggung jawab untuk menunjang pendistribusian barang di seluruh area lampung, membantu menjual serta memasarkan produk agar kebutuhan konsumen dapat terpenuhi. Hal tersebut tidak terlepas dari bagaimana pengelolaan sales territory management dan kecepatan pendistribusian barang ke outlet dengan tujuan mencapai volume penjualan tertentu, mendapatkan laba tertentu, serta meningkatkan penjualan.

Berdasarkan Penelitian Sebelumnya Tentang Analisis Strategi Perusahaan Dalam Ekspansi Pasar Luar Negeri. Hasil yang diperoleh dalam penelitian ini yaitu PT. Semen Indonesia telah berhasil menjadi perusahaan BUMN pertama yang berekspansi ke luar negeri dengan visi yang kuat serta keinginan bertumbuh. Perusahaan juga berhasil dalam melakukan ekspansi pasar keluar negeri dengan strategi yang tepat. Analisis yang mendalam serta selalu mengikuti perkembangan pasar diperlukan oleh perusahaan.(Parrangan et al., 2015). Dalam penelitian ini membahasa tentang ekspansi pasar luar negeri. Dalam penelitian yang peneliti lakukan ini membahas tentang ekspansi territory management.

Kemudian Hasil penelitian menunjukan bahwa pertumbuhan penjualan berpengaruh positif dan signifikan terhadap struktur modal (DER), struktur aktiva berpengaruh positif dan signifikan terhadap struktur modal (DER), dan pertumbuhan aktiva berpengaruh positif dan tidak signifikan terhadap struktur modal (DER). (Suweta \& Dewi, 2016). Dengan demikian dengan bertumbuhnya ekonomi juga mempengaruhi struktur modal.

Pertumbuhan penjualan (sales growth) merupakan selisih antara jumlah penjualan periode ini dengan periode sebelumnya di bandingkan dengan penjualan periode sebelumnya (Harahap, 2008:309). Pertumbuhan penjualan yang tinggi dan stabil dapat berdampak positif terhadap keuntungan perusahaan sehingga menjadi pertimbangan manajemen perusahaan dalam menentukan struktur modal Tingkat pertumbuhan penjualan yang tinggi dapat di pengaruhi dari strategi ekspansi bisnis yang di jalankan oleh perusahaan, seperti seberapa luas cakupan wilayah penjualan yang di cover, bagaimana ketersediaan stok barang di gudang terhadap permintaan outlet atau konsumen, serta berapa lama waktu yang di butuhkan untuk mendistribusikan barang ke outlet, sehingga produk bisa cepat sampai ke keranjang belanja konsumen (impuls buying) dan perusahaan mendapat profit (value) dari transaksi penjualan tersebut.

Berdasarkan hasil observasi pada PT.Karya Anugerah Cabang Lampung di dapat bahwa, lampung adalah salah satu cabang yang baru di buka pada bulan September tahun 2019, bahwa wilayah penjualan (sales territory) yang tercover olehtim salesman belum merata ke seluruh area lampung, Dalam kaitannya dengan sales territory management, hasil penjualan masih belum optimal dan belum sesuai dengan apa yang di harapkan oleh perusahaan. Hal tersebut tentunya harus di benahi agar seluruh manpower tim sales dapat memberikan kontribusi penjualan yang optimal untuk PT.Karya Anugerah Cabang Lampung.

Kondisi seperti di atas disebabkan oleh wilayah penjualan belum merata ke 
seluruh area lampung, mapping pembagian area penjualan untuk tim sales belum optimal, jumlah manpower yang terbatas, jumlah sarana kendaraan pendistribusian barang yang terbatas, budget operasional belum di kelola dengan baik. Jika hal ini tidak segera di selesaikan dengan cepat maka profitabilitas perusahaan akan terganggu, kompetitor akan mengambil alih market share, terjadi lost sales, kebutuhan konsumen akan terganggu karena pasokan barang terbatas. Oleh karena itu kepala cabang PT.Karya Anugerah Jaya Cabang Lampung harus segera membuat strategi dengan seluruh sarana, prasarana dan manpower yang dimiliki.

Salah satunya dengan melakukan ekspansi wilayah penjualan dan remaping area, agar seluruh produk dapat di distribusikan ke suluruh area lampung untuk mencegah terjadi nya kekosongan stok barang (out of stock) di pasaran serta dapat memenuhi kebutuhan konsumen dengan harga yang stabil. Karena dengan begitu pertumbuhan penjualan perusahaan akan terus meningkat.

Berdasarkan uraian di atas makan peneliti tertarik untuk melakukan penelitian dengan judul "Analisis Strategi Ekspansi Sales Territory Management Dalam Meningkatkan Pertumbuhan Penjualan Studi Kasus Pada PT. Karya Anugerah Jaya Cabang Lampung.

\section{METODE PENELITIAN}

Jenis penelitian yang digunakan dalam penelitian ini menggunakan metode deskriptif kualititatif. Bogdan dan Taylor dalam Moleong (2004:3) mengemukakan bahwa penelitian deskriptif merupakan prosedur penelitian yang menghasilkan data deskriptif berupa kata-kata tertulis atau lisan dari orang-orang dan perilaku yang diamati. Penelitian deskriptif sering dikatakan sebagai sebuah penelitian tanpa eksperimen karena peneliti tidak dapat memanipulasi variabel penelitian. Penelitian ini mengambil lokasi di PT. Karya Anugerah Jaya Cabang Lampung.

Sumber data yang digunakan dalam penelitian ini menggunakan data primer dan data skunder. Teknik analisa data dalam penelitian ini menggunakan langkahlangkah sebagai berikut : Reduksi Data (data reduction), Penyajian Data (data display), Penarikan Kesimpulan. Analisa data menggunakan analisa swot dan matrik

\section{HASIL DAN PEMBAHASAN}

Menurut hasil observasi dan wawancara yang dilakukan penulis terhadap sales dan kepala depo PT. Karya Anugerah Jaya Cabang Lampung serta pengumpulan data di lapangan adapun strategi Ekspansi Sales Territory Management dalam Meningkakan Pertumbuhan Penjualan yang digunakan untuk memasuki pasar di lampung adalah dengan memperluas dan mendiversifikasi pasar, yaitu dengan menggunakan langkahlangkah kecil seperti membina hubungan baik (relationship) dengan outlet, serta menyusun serta membuat pengaturan batas wilayah (teritory management). Adapun strategi yang dilakukan sebagai berikut :

\section{Pemetaan wilayah (territory mapping)}

Pemetaan wilayah yaitu menentukan standarisasi coverage terminology atau standarisasi batasan suatu wilayah penjualan yang akan dicover oleh salesman. Dalam memaksimalkan coverage PT. Karya Anugerah Jaya cabang Lampung memakai dua tipe yaitu Direct Coverage dan Indirect Coverage. Coverage merupakan rentang wilayah yang diliput oleh sales force, dimana di dalamnya tercakup sekelompok jumlah outlet yang berpotensi untuk di kunjungi secara teratur. Direct Coverage 
merupakan outlet yang dikunjungi secara reguler oleh salesman dan teregister di accurate sebagai outlet PJP . Contoh nya adalah outlet yang di cover SR Motoris, SR TO (taking order), SR Canvas, SR Stockis. Sedangkan Indirect Coverage merupakan outlet chanel industri yang tidak dikunjungi secara langsung melainkan melalui tim telemarketing. Untuk menentukan outlet tersebut di cover secara direct atau indirect, maka akan di breakdown lagi berdasarkan karakteristik area seperti berikut ini :

Metro City : Kota Jakarta, Bandung, Surabaya, Medan

2nd Tier City : Ibu Kota Provinsi dan kota besar diluar Metro City.

3rd Tier City: Kota/Kabupaten diluar Metro dan 2nd Tier City. Rural/Remote : Daerah Rural, kepulauan.
Parameter yang dijadikan patokan adalah batasan geografis, kondisi pasar, kepadatan penduduk, tujuan belanja, kemampuan sumber daya ekonomi, internal data (rata rata penjulaan per salesman per visit/kunjungan outlet). Setelah menetukan standarisasi coverage terminology atau standarisasi batasan suatu wilayah penjualan yang akan dicover oleh salesman, kemudian PT. Karya Anugerah Jaya Cabang Lampung mempertimbangkan proses pengcoveran outet dengan melihat dua aspek yaitu potensi dan kemudahan akses. Potensi wilayah sangat berpengaruh pada pembagian wilayah, terutama dalam hal kontribusi omset dan penghasilan penjualan. Sebab, kapasitas suatu wilayah yang diproyeksikan dapat mempengaruhi nilai penjualan.

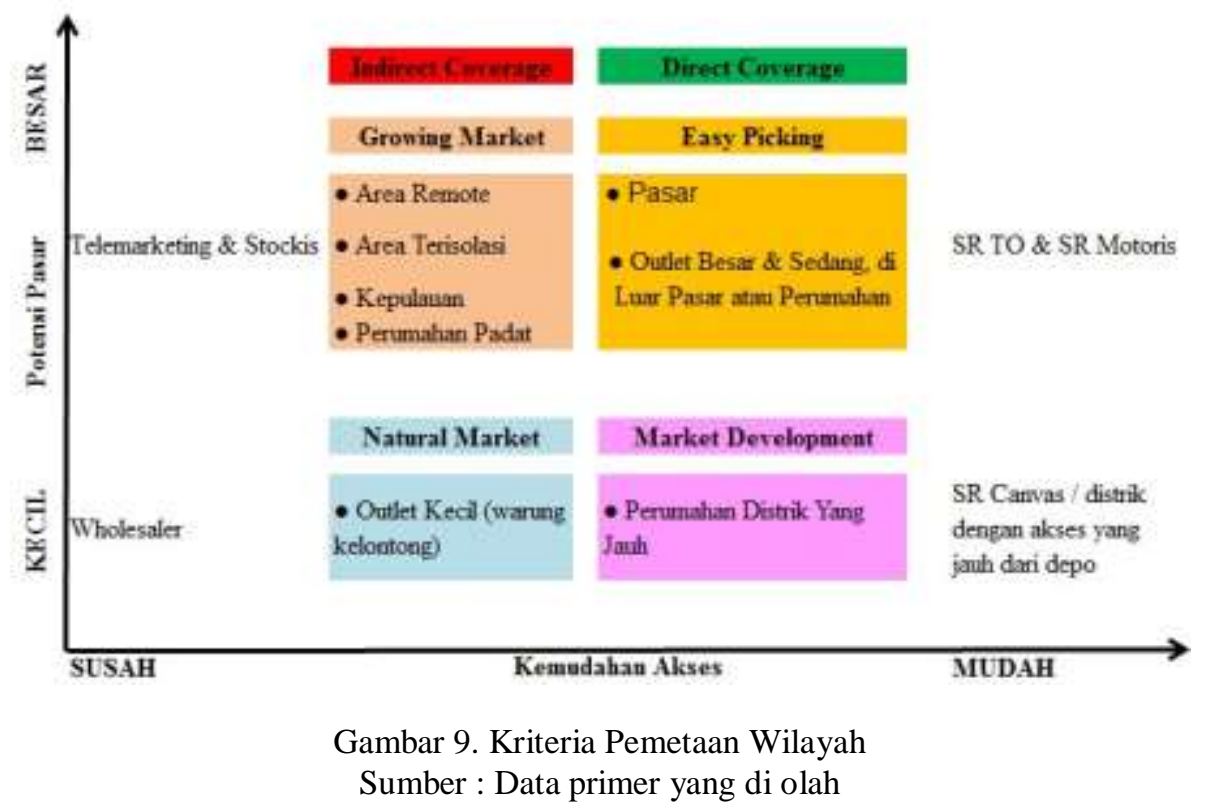

Menurut hasil wawancara yang dilakukan kriteria strategi pemetaan wilayah di bagi menjadi empat kuadran yaitu:

\section{a. Easy Picking}

Potensi besar, akses mudah di jangkau maka harus dilakukan direct delivery serta dicover langsung oleh SR TO \& SR Motoris. b. Market Development

Potensi masih kecil, akses mudah di jangkau maka harus dilakukan direct delivery serta dicover langsung oleh SR Canvass dengan melakukan creative coverage sesuai dengan kebutuhan melalui order by email ke salesman. Syarat creative coverage yaitu distrik berjarak $1-2$ jam dari depo, lokasi di 
perumahan, infrastruktur jalan kurang bagus namun masih bisa dilalui kendaraan roda empat, serta jalan macet. Keuntungan dari strategi creative coverage ini yaitu dapat meningkatkan efektivitas waktu salesman ( mengurangi waktu di jalan +/- 2 jam), dimana tambahan waktu tersebut dapat dapat di gunakan oleh salesman untuk mencari tambahan outlet baru dan turn over, mengurangi biaya transportasi depo, serta meningkatkan keselamatan salesman di jalan (safety)

\section{c. Growing Market}

Potensi cukup besar, akses sulit di jangkau (perjalanan dari depo membutuhkan waktu lebih dari 2 jam, kondisi jalan kurang bagus, daerah sangat padat) maka akan dilakukan indirect delivery dengan agen expedisi dan dapat di cover oleh tim Telemarketing untuk customer industri besar dan Tim Stockis untuk customer toko toko kecil. Stockis merupakan outlet grosir (wholesaler) lokal sebagai bisnis partner untuk membantu pendistribusian produk dengan merk RAJAWALI \& ALCO ke area yang belum dicover (Daerah Remote, Rural, Terisolasi, Pulau) oleh tim reguler depo lampung. Syarat menjadi stockis yaitu memiliki tim order/delivery, mau bekerja sama dengan sharing database toko/pelanggan, kooperatif, soliter/menyendiri. Keuntungan bekerjasama dengan stockis yaitu sebagai agen distribusi yang menjangkau daerah yang belum tercover oleh reguler tim, serta ikut menjaga stabilitas harga, dan sebagai agen aktivitas promosi produk.

\section{d. Natural Market}

Potensi masih kecil, akses sulit di jangkau maka akan dilakukan indirect delivery dengan agen expedisi dan dapat dicover dengan memanfaatkan wholesaler yang akan membantu distribusi barang. Melalui penerapan strategi sales territory management itu, diharapkan bisa memperoleh data analisa yang dapat digunakan PT. Karya Anugerah Jaya sebelum masuk ke suatu wilayah penjualan.

2. Strategi perencanaan pengelolaan wilayah

Strategi perencanaan pengelolaan wilayah yang terdiri dari pembagian wilayah penjualan dan pengelolaan jarak tempuh (route management). Pembagian wilayah penjualan Area Lampung akan dibelah seperti membelah kue yaitu sebagian adalah rencana wilayah yang akan dicover dan sebagian sisanya adalah wilayah yang belum ada rencana untuk dicover oleh salesman seperti yang ditunjukan pada gambar berikut ini : 


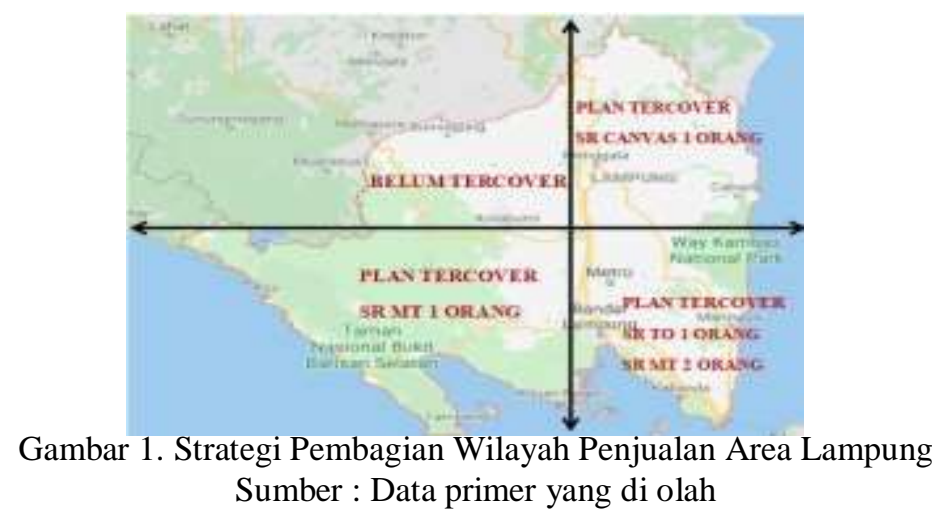

Kemudian setelah maping wilayah yang akan di cover oleh salesman divalidasi, Yoan Eka sebagai Kepala Depo PT. Karya Anugerah Jaya Cabang Lampung akan melakukan breakdown area (per kota/kabupaten) menjadi sub area (per kecamatan) yaitu pembagian wilayah penjualan per masing masing salesman.

Mengingat aktivitas salesman adalah mobile, maka route management sangat diperlukan agar semua outlet dapat dicover dengan efektif dan efisien. Ada banyak model atau pola untuk pembagian wilayah dan pengelolaan jarak tempuh rute kunjungan salesman, dengan kelebihan dan kekurangan masing masing namun bersifat unik. Menurut hasil wawancara penulis dengan seluruh tim sales force PT.Karya Anugerah Jaya Cabang Lampung bahwa strategi yang di terapkan untuk pengelolaan jarak tempuh rute kunjungan yaitu dengan melakukan breakdown per distrik (per kecamatan) kemudian di brekadown kembali per beat (per kelurahan) dan per sub area (per desa/kampung) dimana pengelolaan jarak tempuh rute kunjungan masing masing salesman itu berbeda beda.

Hal ini dikarenakan untuk menyesuaikan letak homebase office (kantor) dengan jarak dan kondisi di lapangan mengingat letak gografis masing masing wilayah yang sangat beragam. Contohnya pola Major-City Pattern, Cloverleaf Pattern, Hopscotch Pattern, atau Straight-Line Pattern. Pola Major-City Pattern yaitu area besar akan dikaplingkapling yang biasanya berdasar letak geografis atau berdasar peta pemerintahan (kecamatan). Model ini dipilih karena ada area / sub area yang berada jauh dari home base, sehingga akan efektif bila di bloking.

Rute kunjungan dengan pola Cloverleaf Pattern akan dibuat melingkar didalam sub area tadi, dan diusahan tidak ada jalan yang sama yang dilewati dua kali (pulang dan pergi pada jalan yang berbeda). Dengan demikian sejak sales force meninggalkan home base, sudah ada outlet yang dikerjakan, sehingga perjalanan sales force lebih efektif.

\section{Monitoring target $\rightarrow$ pencapaian $\rightarrow$ evaluasi.}

Mulai dari pengelolaan kinerja salesman maupun pengembangan wilayah penjualan. Pengelolaan kinerja salesman PT. Karya Anugerah Jaya Cabang Lampung menurut hasil wawancara yang dilakukan dengan Kepala Depo dari PT. Karya Anugerah Jaya Cabang Lampung di mulai dengan standarisasi PJP (plan journey permanent) salesman. Standarisasi PJP salesman yaitu menetapkan standar minimum jumlah outet yng harus di cover oleh masing masing salesman dalam by weekly, monthly, dan yearly frekuensi kunjungan outlet, standar minimum outlet aktif, standar kunjungan (call), standar minimum kunjungan efektif (effective call), standar pencapaian produk fokus, serta standar pencapaian new produk launching yang dapat dimonitoring melalui KPI (key performance indicator) . KPI (key performance indicator) adalah alat untuk memonitor kualitas pengcoveran PJP salesman dengan menggunakan 7 parameter 
yaitu, Volume/Omset, Outlet Aktif, OA Produk Fokus, OA NPL, Attitude dan Return dengan total score maksimal 100 point.

\section{Analisa Swot}

Analisis data dalam penelitian ini dilakukan untuk mengetahui strategi yang diterapkan dan juga menemukan strategi yang tepat untuk PT. Karya Anugerah Jaya. Metode analisis yang digunakan meliputi penggunan matriks IFAS, matriks EFAS, matrik IE dan matriks SWOT. Formulasi yang digunakan peneliti yang pertama adalah mengevaluasi faktor eksternal dan faktor internal perusahaan, kedua melakukan analisis dengan menggunakan matriks IFAS, EFAS, IE dan SWOT, ketiga menyimpulkan hasil analisis sehingga diketahui alternatif strategi.

a. Kekuatan

1. Memiliki kekuatan dari segi keuangan.

Kinerja keuangan PT. Karya Anugerah Jaya sangat baik. Hal ini jika dilihat dari segi pendapataan tahunan perusahaan yang sangat baik. Fakta ini tentunya mengacu pada pendapat yang didapatkan oleh perusahaan. Faktor keuangan menjadi sebuah kekuatan yang sangat vital bagi PT. Karya Anugerah Jaya dalam proses ekspansi pasar

2. Merk dagang yang telah dikenal.

Merk dagang yang kuat merupakan salah satu kekuatan perusahaan untuk menjaga eksistensi dan dapat berkembang. Ketika sebuah perusahaan memiliki merk dagang yang sudah sangat dikenal oleh masyarakat tentunya akan mudah masuk ke pasar sasaran baru. Dengan membawa merk dagang R\&W, ALCO dan HANWE yang telah terdaftar di Badan Pengawas Obat dan Makanan (BPOM RI) serta memperoleh sertifikasi dari Majelis Ulama Indonesia (MUI). Pengaruh merk dagang terhadap loyalitas pelanggan sangat signifikan dan mempengaruhi keberlangsungan produk. Hal ini yang kemudian menjadi sebuah kekuatan dalam melakukan ekspansi pasar.

3. Perusahaan memiliki pengalaman yang kuat di industri pewarna makanan.

Pengalaman perusahaan di industri pewarna makanan dan bahan tambahan pangan lainnya telah dimulai dari tahun 1991. Jika dilihat dari tahun berdirinya perusahaan, maka tidak dapat dipungkiri bahwa perusahaan ini memiliki pengalaman yang panjang di industri pewarna makanan dan bahan tambahan pangan lainnya. Fakta ini yang menjadi sebuah kekuatan menurut peneliti terkait dengan ekspansi pasar yang dilakukan yang akan sangat membantu dalam hal perbaikan manajemen, peningkatan produksi, maupun penerapan strategi yang tepat yang dapat diterapkan pada pasar sasaran

4. Sumber daya manusia yang berkompeten.

Jumlah karyawan tetap yang dimiliki sangat tersebar dalam jenjang umur dan juga sebaran pendidikan yang sangat baik. Selain itu jumlah karyawan yang banyak juga menggambarkan skala organisasi yang besar dan kuat karena ditunjang oleh sumber daya manusia yang berkompeten di bidangnya.

b. Kelemahan

1. Kurangnya kegiatan promosi.

2. Kendala dalam hal komunikasi.

3. Kurangnya link pemasaran. 
c. Peluang

1) Pertumbuhan industri pewarna makanan tinggi.

2) Konsumsi yang tinggi.

d. Ancaman

1) Ancaman dari kompetitor yang kompetitif dan perusahaan pendatang baru.

Persaingan sangat kompetitif di industri pewarna makanan akan menjadi sebuah perhatian khusus. Terkait dengan fakta di lapangan bahwa industri pewarna makanan di regional dihuni oleh perusahaan besar yang kemudian akan membuat perusahaan akan kesusahan untuk bersaing di pasar yang telah dihuni pemain besar dan jika tidak menggunakan strategi yang tepat. Pendatang baru pada industri semen regional juga tidak dapat dipandang sebelah mata.

2) Kurangnya pemahaman tim pada target pasar.

Kurangnya pemahaman tim pada target pasar yang ingin ia capai. Minimnya data yang dimiliki oleh tim marketing dan sales membuat mereka melakukan pemasaran dengan sistem yang tidak memiliki arah yang jelas. Strategi yang dipakai pun hanya gambaran dan jauh dari keadaan sebenarnya yang akan dihadapi oleh tim

\section{Matrik Swot}

Berdasarkan matriks SWOT yang telah disajikan diatas, maka dapat diketahui macam-macam strategi dari empat kuadran yang tersedia dengan memanfaatkan kekuatan, kelemahan, peluang serta ancaman yang sudah dianalisis sebelumnya. Berikut adalah penjelasan dari strategi yang diperoleh dari matriks SWOT

\section{a. Strategi S-O (Strenght-Opportunities)}

Strategi ini menciptakan strategi dengan menggunakan kekuatan dari perusahaan untuk memanfaatkan peluang yang ada, berikut adalah strategi yang dihasilkan:
1) Meningkatkan kapasitas produksi untuk mengejar target pertumbuhan.

2) Mengejar target penjualan dengan memanfaatkan brand image.

3) Memperluas pangsa pasar dengan pengalaman yang dimiliki.

4) Kondisi keuangan perusahaan yang relatif sangat baik.

\section{b. Strategi S-T (Strenght-Threats)}

Strategi ini digunakan untuk menciptakan strategi dengan menggunakan kekuatan yang dimiliki oleh perusahaan untuk mengatasi ancaman. Berikut adalah strategi yang dihasilkan

1) Memanfaatkan pengalaman untuk bersaing dengan kompetitor.

2) Kondisi keuangan perusahaan yang relatif sangat baik.

3) Menggunakan brand image untuk bersaing dengan pendatang baru.

4) Menggunakan kekuatan finansial dengan strategi yang tepat.

5) Memanfaatkan SDM yang berkompeten.

\section{c.Strategi W-O (Weakness- \\ Opportunities)}

Strategi ini diterapkan dengan cara memanfaatkan peluang yang dimiliki perusahaan untuk meminimalkan kelemahan yang dimiliki perusahaan. Berikut adalah beberapa strategi yang dihasilkan,

1) Analisis mendalam sebelum melakukan promosi.

2) Memanfaatkan SDM berkompeten sesuai bidangnya

\section{d. Strategi W-T (Weakness-Threats)}

Strategi ini digunakan pada strategi defensif, dimana strategi ini diciptakan untuk meminimalkan kelemahan yang dimiliki perusahaan serta menghindari ancaman. Berikut adalah strategi yang dihasilkan,

1. Implementasi strategi bersaing di industri 
2. Melakukan pendidikan dan pelatihan berkelanjutan terhadap SDM yang dimiliki.

\section{KESIMPULAN}

Berdasarkan hasil analisis dan pembahasan tentang maka dapat diambil kesimpulan bahwa strategi yang digunakan PT. Karya Anugerah Jaya Cabang Lampung dalam ekspansi sales territory management adalah melakukan pemetaan wilayah penjualan, perencanaan pengelolaan wilayah, dan melakukan monitoring target pencapaian - evaluasi.

Berdasarkan analisis SWOT dan Matriks SWOT menunjukkan bahwa PT. Karya Anugerah Jaya memiliki kekuatan dan peluang yang lebih besar dibandingkan dengan kelemahan dan ancaman artinya bahwa perusahaan dalam kondisi yang baik. Kekuatan yang dimiliki oleh PT. Karya Anugerah Jaya terletak pada kekuatan dari segi keuangan, merk dagang yang telah dikenal, perusahaan memiliki pengalaman yang kuat di industri pewarna makanan, sumber daya manusia yang berkompeten.

$$
\text { Oleh karena itu PT.Karya }
$$

Anugerah Jaya Cabang Lampung memiliki peluang besar untuk terus melakukan ekspansi sales territory management khususnya wilayah yang belum tercover oleh tim salesman seperti Kabupaten Lampung Barat, Kabupaten Pesisr Barat, Kabupaten Way Kanan, Kabupaten Mesuji, Kabupaten Lampung Utara, dan Kabupaten Tulang Bawang Barat sehingga persentase pertumbuhan penjualan bisa lebih maksimal lagi.

\section{DAFTAR PUSTAKA}

Fajar, R. (2012). Model Sales Territory Management "Cluster War" Sebagai Bentuk Strategi Pemasaran Pada Pt. Telkomsel Sub Branch Malang. Jurnal Ilmiah Mahasiswa Feb, Vol 1. No. $1,12$.
Kerjaya, H. (2016). Hermawan Kartajaya On Marketing Mix. Mizan Pustaka.

Mulyadi. (2016). Sistem Akutansi. Selemba Empat.

Naray, A. R., \& Mananeke, L. (2015). Pengaruh Pertumbuhan Penjualan, Struktur Aktiva Dan Ukuran Penjualan Terhadap Struktur Modal Pada Bank Pemerintah Kategori Buku 4. Jurnal Emba, Vol 3. No. 2, 12.

Parrangan, E. R., Kumadji, S., \& Yulianto, E. (2015). Analisis Strategi Perusahaan Dalam Ekspansi Pasar Luar Negeri. Jurnal Administrasi Bisnis (Jab), Vol 26. No. 2, 10.

Pitoy, C. V., Tumbel, A., \& Tielung, M. (2016). Analisis Strategi Bersaing Dalam Persaingan Usaha Bisnis Document Solution (Studi Kasus Pada Pt. Astragraphia, Tbk Manado). 16(03), 11.

Purboningrum, E. L. (2018). Analisis Strategi Ekspansi Dalam Pengembangan Bisnis Di Pasar Global (Studi Kasus Pada Pt Semen Indonesia (Persero) Tbk. Dalam Akuisisi Thang Long. Jurnal Administrasi Bisnis (Jab), Vol. 58 No. $1,10$.

Royan, F. M. (2014). Bisnis Model Kanvas Distributor. Gramedia Pustaka Utama.

Suweta, N. M. N. P. D., \& Dewi, M. R. (2016). Pengaruh Pertumbuhan Penjualan, Struktur Aktiva, Dan Pertumbuhan Aktiva Terhadap Struktur Modal. E-Jurnal Manajemen Unud, Vol. 5 No. 8. 